\title{
Study on the Interaction between Doxorubicin and Deoxyribonucleic Acid with the use of Methylene Blue as a Probe
}

\author{
Reza Hajian,* Nafiseh Shams and Majid Mohagheghian \\ College of Science, Chemistry Department, Islamic Azad University Branch of Gachsaran, \\ Gachsaran, 75818-63876, Iran
}

\begin{abstract}
Neste trabalho, a interação de doxorrubicina com DNA (obtido de timo de bezerro) em fita dupla foi investigada através de técnicas de espectrofotometria UV-Vis, voltametria e espectrofluorometria, usando azul de metrileno (MB) como marcador. O comportamento voltamétrico da doxorrubicina foi investigado em eletrodo de carbono vítreo usando voltametria de pulso diferencial. A doxorrubicina é reduzida, produzindo um pico de redução. Os dois estudos, espectrofotometria UV-Vis e voltametria de pulso diferencial, confirmam a reação de intercalação. Os resultados mostraram que a doxorrubicina e a molécula de MB foram intercaladas na dupla hélice do DNA. A constante de ligação aparente de doxorrubicina com DNA foi $3,2 \times 10^{4} \mathrm{~L} \mathrm{~mol}^{-1}$. O sinal de fluorescência da doxorrubicina e azul de metileno é suprimido com a adição de DNA. A equação de Stern-Volmer baseou-se na supressão do sinal de fluorescência da doxorrubicina.
\end{abstract}

In this work, the interaction of doxorubicin with calf thymus double strand Deoxyribonucleic acid (ds-DNA) has been investigated with the use of Methylene Blue (MB) dye as a probe by the application of UV-Vis spectrophotometry, voltammetry and spectrofluorometry. The voltammetric behavior of doxorubicin has been investigated at glassy carbon electrode using differential pulse voltammetry. Doxorubicin is reduced, yielding one reduction peak. Both UV-Vis spectrophotometry and differential pulse voltammetry studies confirm the intercalation reaction. The results showed that both doxorubicin and the MB molecule could intercalate into the double helix of the DNA. The apparent binding constant of doxorubicin with DNA has been found to be $3.2 \times 10^{4} \mathrm{~L} \mathrm{~mol}^{-1}$. The fluorescence signal of doxorubicin and methylene blue was quenched with DNA addition. The Stern-Volmer equation was plotted based on quenching fluorescence signal of doxorubicin.

Keywords: doxorubicin, DNA, chemotherapy, spectrophotometry, voltammetry, spectrofluorometry

\section{Introduction}

Study of interactions between drugs and DNA is very interesting and significant not only in understanding the mechanism of interaction, but also for the design of new drugs. ${ }^{1,2}$ However mechanism of interactions between drug molecules and DNA is still relatively little known. It is necessary to introduce more simple methods for investigating the mechanism of interaction. By understanding the mechanism of interaction, designing of new DNA-targeted drugs and the screening of these in vitro will be possible.

A great variety of substances, including several agents of importance in cancer chemotherapy, ${ }^{3}$ are known to bind to DNA by intercalation. ${ }^{4}$ Attention has been

*e-mail: hajian@iaug.ac.ir concentrated on the classical intercalating drugs, acridines and ethidium bromide. ${ }^{4-6}$ Studies on the binding of various dyes, drugs and antibiotics to DNA and chromatin have contributed to the understanding of the structure of these macromolecules, ${ }^{6-14}$ and have suggested possible mechanisms of the biological activity of some drugs. ${ }^{3}$ Molecular models of the intercalation of some drugs into DNA have been described, ${ }^{4}$ and it is already apparent that differences in the binding specificity must be expected. ${ }^{15}$ Indeed, different intercalating agents produce different effects on DNA. ${ }^{6}$ It remains to be elucidated if such differences may influence their selectivity in drug action.

Chemotherapy is an important part of the program for cancer treatment. A lot of compounds are developed as potential candidates for anticancer drugs, but only a handful of them have become effective clinical drugs. ${ }^{16,17}$ The development of new drugs requires that the underlying 
mechanism of the drug action at the cellular and molecular levels be better understood. Many anticancer drugs have been known to interact with DNA to exert their biological activities.

Methylene blue (MB, Scheme 1) is a phenothiazinyl dye, which is a kind of photosensitizer drug molecules showing promising applications in the photodynamic therapy (PDT) for anticancer treatment. ${ }^{18-20}$ Due to its planar structure, which is similar to acridine dyes, MB can interact easily with DNA and has been used as a stain agent for DNA. ${ }^{21}$

The interaction of methylene blue with DNA has been studied with various methods. ${ }^{22-26}$ Most studies have indicated that at low ionic strength buffer and low concentration of DNA, the major binding mode of MB with DNA is through intercalation. ${ }^{24,27}$ Moreover, MB has a low toxicity. Data from material safety data sheet of Vanderbilt Environmental Health \& Safety (VEHS) show that MB is slightly hazardous in case of skin contact, eye contact, ingestion, inhalation and no evidence shows that MB is a carcinogenic compound. ${ }^{28}$

The interaction of doxorubicin (Scheme 2) (the main representative of the anthracycline group of antibiotics) with DNA is of general interest in connection with questions regarding drug-nucleic acid interactions, since its biological activity is thought to reside in the ability to bind to DNA. ${ }^{29}$ According to our knowledge, study on the interaction between doxorubicin and DNA have been reported by resonance Raman spectroscopy, ${ }^{30}$ FT-IR, ${ }^{31}$ and circular dichromism spectroscopies. ${ }^{32}$

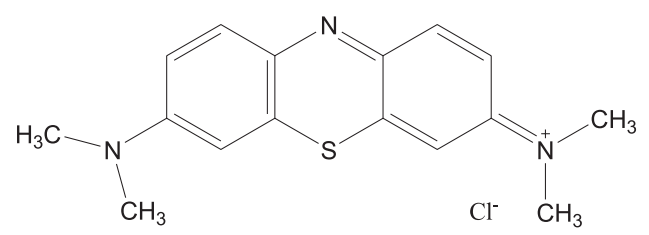

Scheme 1. Molecular structure of methylene blue.

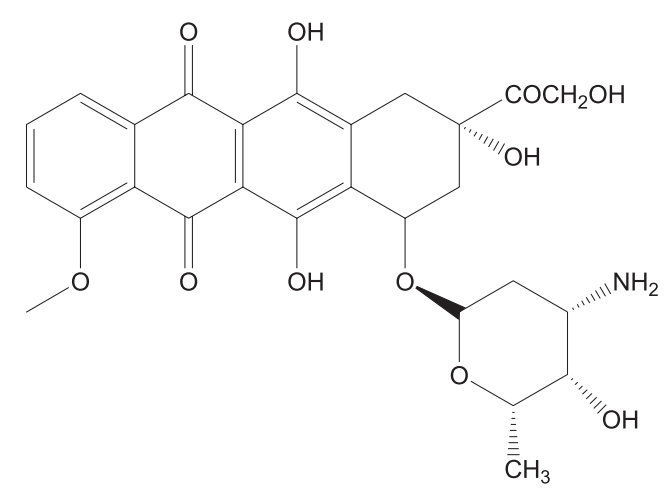

Scheme 2. Molecular structure of doxorubicin.

In this work, the interaction between doxorubicin and calf thymus DNA has been investigated by absorption and fluorescence spectroscopies as well as by electrochemical methods. Because the interaction between MB and DNA is known (intercalation mechanism), we used it as a probe for comparing its behavior against DNA in comparison with doxorubicin. The results showed that doxorubicin, similarly to methylene blue can intercalate into the double helix of DNA. The apparent binding constant of doxorubicin-DNA complex is found to be $3.2 \times 10^{4} \mathrm{~L} \mathrm{~mol}^{-1}$. The aim of this study is to find the mode of the interaction between doxorubicin and DNA by using spectroscopy and electrochemical methods. This will help us to design new drugs, which have biological and antitumour activities. The advantages of the proposed method involve simplicity and cheap devices.

\section{Experimental}

\section{Reagents}

All the chemicals were of analytical grade and have been purchased from Aldrich. Doubly distilled water was used throughout.

Stock solution $\left(3.7 \times 10^{-3} \mathrm{~mol} \mathrm{~L}^{-1}\right)$ of doxorubicin dissolved in sodium chloride $\left(0.01 \mathrm{~mol} \mathrm{~L}^{-1}\right)$ was purchased from Pharmacia Limited, Italy.

A $1.0 \times 10^{-3} \mathrm{~mol} \mathrm{~L}^{-1} \mathrm{MB}$ solution was prepared by dissolving $0.0374 \mathrm{~g}$ of methylene blue. $3 \mathrm{H}_{2} \mathrm{O}$ in water and the solution was diluted to $100 \mathrm{~mL}$ with water in a $100 \mathrm{~mL}$ volumetric flask. The solution was kept in a refrigerator at $4{ }^{\circ} \mathrm{C}$ and in darkness. More dilute solutions were prepared by appropriate dilution with water.

Calf thymus DNA was used without further purification. Its concentration was determined spectrophotometrically using the molar absorbtivity value, $\varepsilon_{260}=6600 \mathrm{~mol}^{-1} \mathrm{~cm}^{-1} .25$ For making a $1.76 \times 10^{-4} \mathrm{~mol} \mathrm{~L}^{-1} \mathrm{DNA}, 0.010 \mathrm{~g}$ of calf thymus DNA was dissolved in $0.010 \mathrm{~mol} \mathrm{~L}^{-1}$ phosphate buffer (pH 7.4) and $0.05 \mathrm{~mol} \mathrm{~L}^{-1}$ sodium chloride solution in a $25 \mathrm{~mL}$ volumetric flask.

All solutions were adjusted with the phosphate buffer (0.01 mol L-1, pH 7.4) in the presence of $0.05 \mathrm{~mol} \mathrm{~L}^{-1}$ sodium chloride.

\section{Apparatus}

UV-Vis absorption spectra were measured on an Agilent UV-Vis spectrophotometer, Perkin Elmer (Lambda 25), with the use of $1.0 \mathrm{~cm}$ quartz cells.

Voltammetric measurements were carried out using an EG\&G instrument, Model 394, with three-electrodes containing glassy carbon as a working electrode, a platinum electrode as an auxiliary electrode and a Saturated Calomel Electrode (SCE) as a reference electrode. 
All spectrofluorometric assays were made on a spectrofluoromrtric, JASCO, equipped with a xenon lamp and a $1.0 \mathrm{~cm}$ quartz cell. Both excitation and emission slits were set at $5 \mathrm{~nm}$, and the scan rate at $500 \mathrm{~nm} \mathrm{~min}^{-1}$. A Pentium IV (2.0 MHz) computer controlled all of the settings and data processing.

A Mettler MP $225 \mathrm{pH}$ meter with a combined glass electrode was used for $\mathrm{pH}$ measurements.

All experiments were carried out at room temperature $\left(25 \pm 1^{\circ} \mathrm{C}\right)$ in $0.01 \mathrm{~mol} \mathrm{~L}^{-1}$ phosphate buffer solution, $\mathrm{pH} 7.4$ containing $0.05 \mathrm{~mol} \mathrm{~L}^{-1} \mathrm{NaCl}$.

\section{Preparation of the glassy carbon electrode}

Before each experiment, glassy carbon (GC) electrode was first polished to a mirror finish with $0.05-\mu \mathrm{m}$ alumina polishing suspension (Buehler) and then cleaned sonication in acetone and water, respectively, for $3 \mathrm{~min}$. Then it was transferred into a blank buffer solution (phosphate buffer (0.01 mol L-1, pH 7.4) plus $\left.\mathrm{NaCl}\left(0.05 \mathrm{~mol} \mathrm{~L}^{-1}\right)\right)$, and a continuous voltammetric scan $(n=5)$ with a scan rate of $50 \mathrm{mV} \mathrm{s}^{-1}$ was carried out in the range of 0.0 to $+1 \mathrm{~V}$.

\section{Results and Discussion}

\section{Spectrophotometric studies}

\section{Interaction of doxorubicin with ds-DNA}

UV-Vis absorption spectra have been obtained by titration of a $1.0 \times 10^{-5} \mathrm{~mol} \mathrm{~L}^{-1}$ doxorubicin solution with increasing concentration of ds-DNA (Figure 1). There is an absorption band at $493.4 \mathrm{~nm}$ in the absence of ds-DNA. With the increase of DNA concentration, the absorption band decreases continuously. It is similar to the phenomenon caused by the interaction between DNA and its typical intercalate ${ }^{26}$ Based on the variations of absorbance at the absorption band, the binding constant, $\mathrm{K}$, of complex-DNA can be obtained according to the following equation: ${ }^{33}$

$\frac{\mathrm{A}_{0}}{\mathrm{~A}-\mathrm{A}_{0}}=\frac{\varepsilon_{\mathrm{G}}}{\varepsilon_{\mathrm{H}-\mathrm{G}}-\varepsilon_{\mathrm{G}}}+\frac{\varepsilon_{\mathrm{G}}}{\varepsilon_{\mathrm{H}-\mathrm{G}}-\varepsilon_{\mathrm{G}}} \frac{1}{\mathrm{~K}[\mathrm{DNA}]}$

Where " $\mathrm{A}_{0}$ " and " $\mathrm{A}$ " are the absorbance of drug in the absence and presence of DNA, $\varepsilon_{\mathrm{G}}$ and $\varepsilon_{\mathrm{H}-\mathrm{G}}$ are their absorption coefficients, respectively. $G$ and $H-G$ represent to drug and drug-DNA species respectively. The result of fitting the experimental data with equation 1 is shown in Figure 2. It suggests that the complex of doxorubicin with ds-DNA is relative to a $1: 1$ complex. From the plot of $\mathrm{A}_{0} /\left(\mathrm{A}-\mathrm{A}_{0}\right)$ to $1 /[\mathrm{DNA}]$, the ratio of the intercept to the slope gives the binding constant, $\mathrm{K}=3.2( \pm 0.23) \times 10^{4} \mathrm{~L} \mathrm{~mol}^{-1}(\mathrm{n}=4)$.

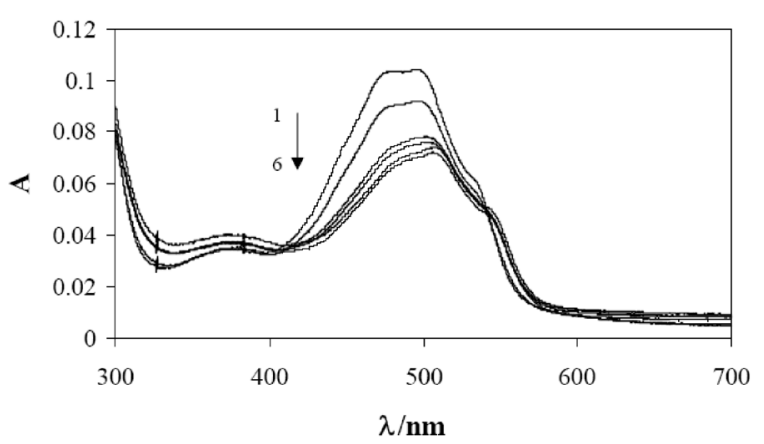

Figure 1. Absorption spectra of doxorubicin in the presence of ds-DNA at different concentrations. $C_{\mathrm{DNA}}=0,5.0,10.0,15.0,20.0$ and $25.0 \mu \mathrm{mol} \mathrm{L}^{-1}$ for curves 1-6, and $10.0 \mu \mathrm{mol} \mathrm{L^{-1 }}$ doxorubicin in phosphate buffer (0.01 $\left.\mathrm{mol} \mathrm{L}^{-1}, \mathrm{pH} 7.4\right)$ plus $\mathrm{NaCl}\left(0.05 \mathrm{~mol} \mathrm{~L}^{-1}\right)$.

In order to clarify the presence of interaction between doxorubicin and ds-DNA, the absorption spectra of methylene blue in the presence of ds-DNA was compared with doxorubicin-DNA spectra.

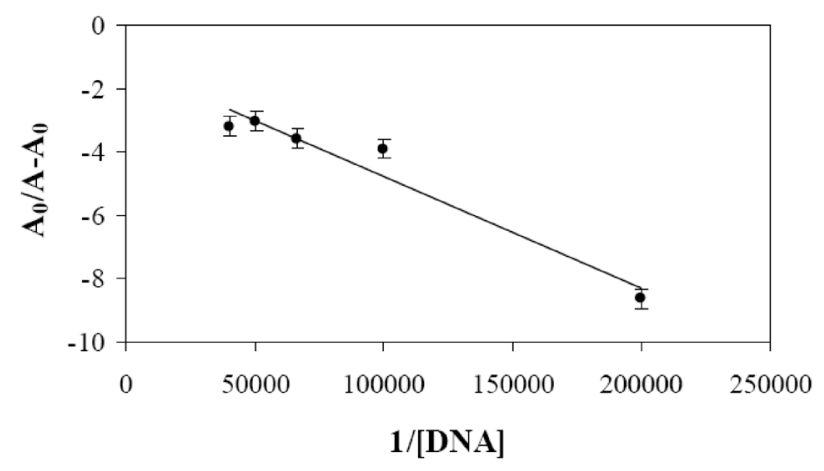

Figure 2. The plot of $\left(\mathrm{A}_{0} / \mathrm{A}-\mathrm{A}_{0}\right)$ versus $1 /$ [DNA]. Conditions: phosphate buffer $\left(0.01 \mathrm{~mol} \mathrm{~L}^{-1}\right.$, pH 7.4) plus $\mathrm{NaCl}\left(0.05 \mathrm{~mol} \mathrm{~L}^{-1}\right), 10.0 \mu \mathrm{mol} \mathrm{L}^{-1}$ doxorubicin.

\section{Interaction of $M B$ with ds-DNA}

The changes of the absorption spectra of $\mathrm{MB}$ are shown in Figure 3. The absorption spectra of MB upon increasing the concentration of DNA showed gradually decreases in the peak intensities with a red shift. This phenomena is usually associated with molecular intercalation into the base stack of the ds-DNA. ${ }^{34}$ The strength of this electronic interaction is expected to decrease as the cube of the distance between the chromophore and the DNA bases. ${ }^{35,36}$ By decreasing the distance between intercalated MB and DNA bases, hypochromism take place obviously. Thus, this is consistent with the combination of MB $\pi$ electrons and $\pi$ electrons of DNA's bases. ${ }^{36}$ Consequently, the energy level of the $\pi-\pi^{*}$ electron transition decreases, which causes a red shift. This contributes to the hypochromic effect discussed above.

Competitive interaction of doxorubicin with $M B-d s-D N A$

The observed band of MB-doxorubicin complex at $668 \mathrm{~nm}$ gradually decreases in intensity with the increasing 


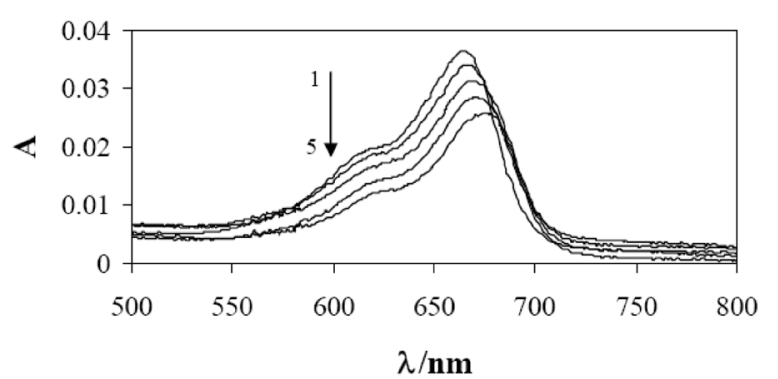

Figure 3. Absorption spectra of methylene blue in the presence of DNA at different concentrations. $C_{\mathrm{DNA}}=0.0,11.7,23.4,35.1$ and $46.8 \mu \mathrm{mol} \mathrm{L}^{-1}$ for curves $1-5$, and $C_{\mathrm{MB}}=1 \mu \mathrm{mol} \mathrm{L} \mathrm{L}^{-1}$ in phosphate buffer $\left(0.01 \mathrm{~mol} \mathrm{~L}^{-1}\right.$, $\mathrm{pH}$ 7.4) plus $\mathrm{NaCl}\left(0.05 \mathrm{~mol} \mathrm{~L}^{-1}\right)$.

concentration of the added doxorubicin. This band almost shifts towards the blue end of the spectrum with the appearance of a new peak at $504 \mathrm{~nm}$, which increases progressively in intensity (Figure 4). An isobestic point at $580 \mathrm{~nm}$ provides evidence that a new species is forming during the competitive interaction. The observed changes in intensity and position of the bands with increasing amounts of doxorubicin added to the MB-DNA solution, suggest that doxorubicin intercalates into the double helix of the DNA through exchanging with the MB fluorophoric dye probe.

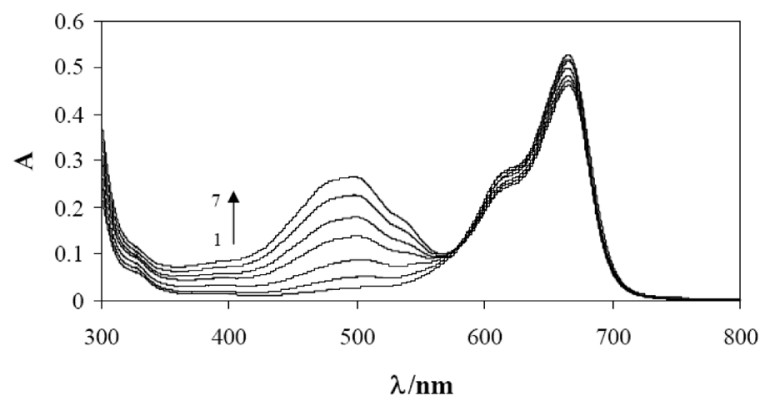

Figure 4. Absorption spectra of the competitive reaction between doxorubicin and methylene blue bonded to DNA. $\mathrm{C}_{\text {doxorubicin }}=0.0,6.8,13.6$, $20.4,27.2,34.0$ and $40.8 \mu \mathrm{mol} \mathrm{L}^{-1}$ for curves $1-7, \mathrm{C}_{\mathrm{MB}}=10.0 \mu \mathrm{mol} \mathrm{L}^{-1}$ and $\mathrm{C}_{\mathrm{DNA}}=10.0 \mu \mathrm{mol} \mathrm{L}^{-1}$ in phosphate buffer $\left(0.01 \mathrm{~mol} \mathrm{~L}^{-1}, \mathrm{pH}\right.$ 7.4) plus $\mathrm{NaCl}\left(0.05 \mathrm{~mol} \mathrm{~L}^{-1}\right)$.

\section{Electrochemical studies}

\section{Interaction of doxorubicin with ds-DNA}

Typical differential pulse voltammetry behavior of doxorubicin in the absence and presence of DNA has been shown in Figure 5. Addition of DNA causes the peak current of the oxidation wave of doxorubicin to diminish considerably. Additionally, the peak potential $\left(\mathrm{E}_{\mathrm{pc}}\right)$ shifts to more positive values, from 0.41 to $0.45 \mathrm{~V}$ (vs. SCE), indicating that the action of doxorubicin with ds-DNA may be intercalation. ${ }^{37,38}$

According to the equation $\Delta \mathrm{E}_{\mathrm{b}}^{0^{\prime}}-\Delta \mathrm{E}_{\mathrm{f}}^{0,}=59.15 \log \left(\mathrm{K}_{\mathrm{R}} / \mathrm{K}_{\mathrm{O}}\right){ }^{37}$ where $\mathrm{E}_{\mathrm{b}}^{0}$ and $\mathrm{E}_{\mathrm{f}}^{0}$ are the formal potentials of the drug in the presence and absence of DNA and $\mathrm{k}_{\mathrm{R}} / \mathrm{k}_{\mathrm{O}}$ is the ratio of the formation constant between drug and DNA in the reduction and oxidation forms, the value was calculated to be 4.7. This suggests that the formation constant for the doxorubicin binding to DNA is about 4.7 times larger than in its oxidized form.

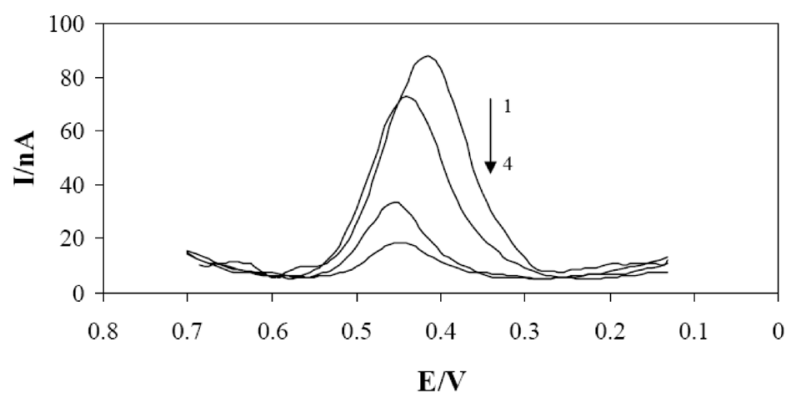

Figure 5. Differential pulse voltammograms of doxorubicin ( 0.7 to $0.2 \mathrm{~V} /$ $\mathrm{SCE}$ ) in the presence of different concentrations of DNA on the surface of glassy carbon electrode (GCE). $C_{\mathrm{DNA}}=0.0,1.0,10.0$ and $50.0 \mu \mathrm{mol} \mathrm{L}^{-1}$ for curves $1-4$, and $C_{\text {doxorubicin }}=10 \mu \mathrm{mol} \mathrm{L}^{-1}$ in phosphate buffer $\left(0.01 \mathrm{~mol} \mathrm{~L}^{-1}\right.$, $\mathrm{pH}$ 7.4) plus $\mathrm{NaCl}\left(0.05 \mathrm{~mol} \mathrm{~L}^{-1}\right)$, scan rate $33.3 \mathrm{mV} \mathrm{s}^{-1}$.

\section{Interaction of $M B$ with ds-DNA}

A differential pulse voltammogram of the MB dye probe (Figure 6) at a glassy carbon electrode exhibits a cathodic peak. The peak at approximately $-0.13 \mathrm{~V}$ corresponds to the reduction of MB. As the concentration of ds-DNA is increased, no new waves are formed, but a decrease in peak current for reduction peak occurs. Positive shift was observed for reduction peak potential, which again suggests that the MB molecule has intercalated into the DNA.

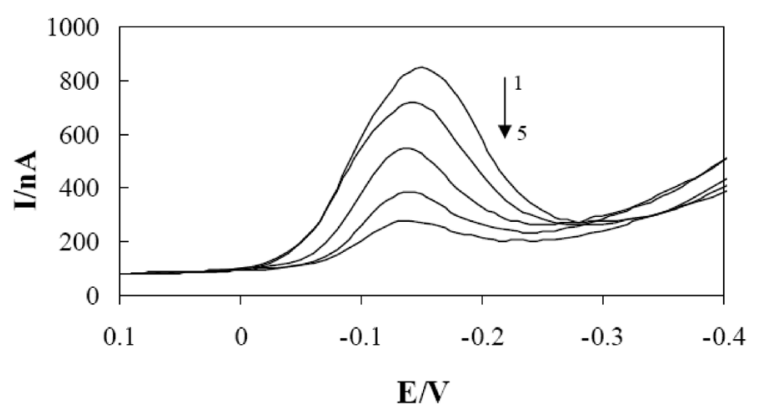

Figure 6. Differential pulse voltammograms of methylene blue in the presence of different concentrations of DNA. $C_{\mathrm{DNA}}=0.0,1.9,3.8,5.7$ and $7.6 \mu \mathrm{mol} \mathrm{L}^{-1}$ for curves $1-5$, and $C_{\mathrm{MB}}=10 \mu \mathrm{mol} \mathrm{L} \mathrm{L}^{-1}$ in phosphate buffer $\left(0.01 \mathrm{~mol} \mathrm{~L}^{-1}, \mathrm{pH} 7.4\right)$ plus $\mathrm{NaCl}\left(0.05 \mathrm{~mol} \mathrm{~L}^{-1}\right)$, scan rate $50 \mathrm{mVs}^{-1}$.

In order to demonstrate that the decrease in current is not due to the increased viscosity of the solution or the blockage of the electrode surface by ds-DNA adsorption, a special differential pulse voltammetry experiment has been designed with a solution with or without DNA (Figure 7). In these solutions, the ions don't interact with DNA because of coulombic repulsion between their negative charges ${ }^{39}$ It shows that the addition of DNA only affects the current slightly, and there was no shift in the peak potential. Therefore, there are only few effects of the 
change in viscosity (ds-DNA addition) on the diffusion, and no significant obstruction on the GC surface from ds-DNA adsorption. The great decrease in current of doxorubicin in the presence of ds-DNA could be attributed to the decrease of diffusion coefficient of the complex and decreasing in the free drug concentration because of the complex formation.

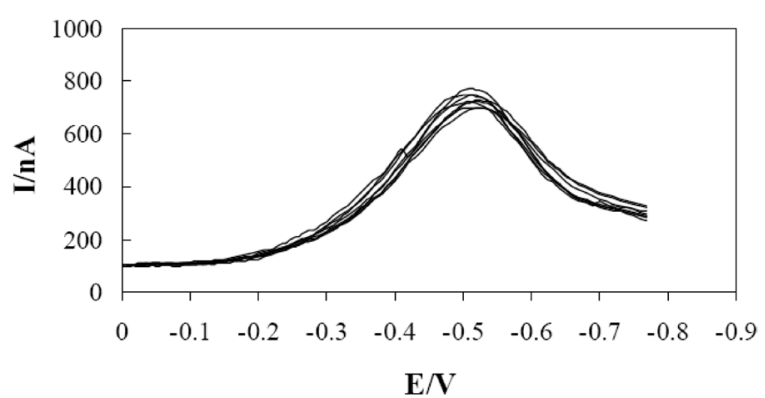

Figure 7. Differential pulse voltammograms of in the presence of different concentrations of DNA. $C_{\mathrm{DNA}}=0.0,1.9,3.8,5.7$ and $7.6 \mu \mathrm{mol} \mathrm{L}^{-1}$, and $\left[\mathrm{K}_{4} \mathrm{Fe}(\mathrm{CN})_{6}\right]=10 \mu \mathrm{mol} \mathrm{L}^{-1}$ in phosphate buffer $\left(0.01 \mathrm{~mol} \mathrm{~L}^{-1}, \mathrm{pH} 7.4\right)$ plus $\mathrm{NaCl}\left(0.05 \mathrm{~mol} \mathrm{~L}^{-1}\right)$, scan rate $50 \mathrm{mVs}^{-1}$.

\section{Spectrofluorometry studies}

\section{Interaction of doxorubicin with ds-DNA}

Doxorubicin has two maxima fluorescence peaks at $c a$. $560 \mathrm{~nm}$ and $c a .590 \mathrm{~nm}$ when excited at $480 \mathrm{~nm}$. When the ds-DNA solution was added to the doxorubicin solution, the fluorescence intensity decreased (quenched fluorescence). Figure 8 shows the fluorescence spectra of doxorubicin in the presence and absence of calf thymus DNA. The inset of Figure 8 shows a Hill plot of fluorescence quenching as a function of increasing ds-DNA concentration. Also, the plot in Figure 9 shows the variation of the fluorescence intensity of doxorubicin as a function of $C_{\mathrm{DNA}} / C_{\text {doxorubicin }}$ ratio. It is clear that the fluorescence of doxorubicin was not completely quenched by ds-DNA, indicating that only a fraction of the binding sites quenches the fluorescence.

The fluorescence quenching of doxorubicin in the presence of DNA may be caused by the fact that, by diffusion of drug into the double helix of DNA, the active surface of doxorubicin will be reduced upon excitation radiation.

\section{Interaction of $M B$ with ds-DNA}

Figure 10 shows the synchronous fluorescence spectra of MB with ds-DNA. It can be seen that the fluorescence of MB was efficiently quenched at the maximum emission wavelength $678 \mathrm{~nm}$ upon addition of ds-DNA, indicating that the MB binding to DNA changes the excited state electronic structure of MB fluorophore. ${ }^{34}$

The fluorescence quenching constant, $\mathrm{K}_{\mathrm{SV}}$, evaluated using the Stern-Volmer equation 2 was $7.60 \times 10^{3} \mathrm{~L} \mathrm{~mol}^{-1}$. In equation $2, \mathrm{~F}_{0}$ and $\mathrm{F}$ are the fluorescence intensities in

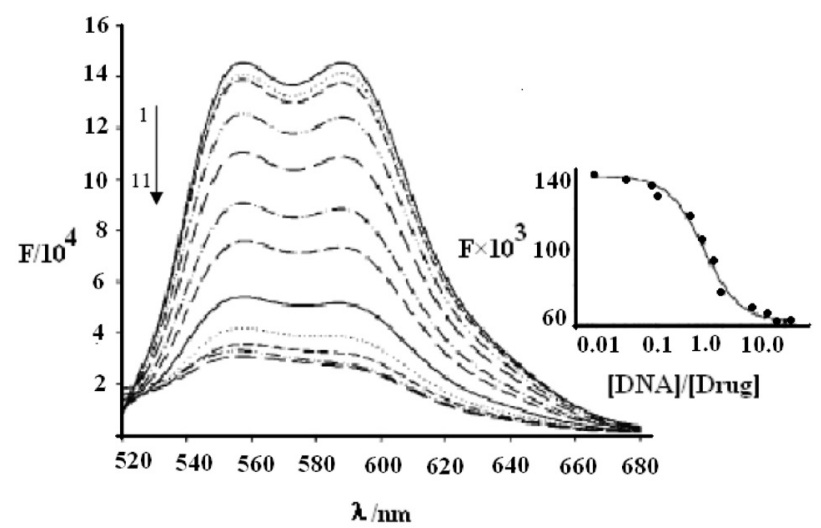

Figure 8. Emission fluorescence spectra of doxorubicin in the presence of DNA. ${ }^{40} C_{\mathrm{DNA}} / C_{\text {doxorubicin }}=0.0,0.01,0.03,0.1,0.3,0.5,1.0,3.0,5.0,7.0$ and 10.0 for curves $1-11$, and $C_{\text {doxorubicin }}=1.5 \mu \mathrm{mol} \mathrm{L}^{-1}$ in phosphate buffer (0.01 mol L-1, pH 7.4) plus $\mathrm{NaCl}\left(0.05 \mathrm{~mol} \mathrm{~L}^{-1}\right)$, excitation wavelength $480 \mathrm{~nm}$.

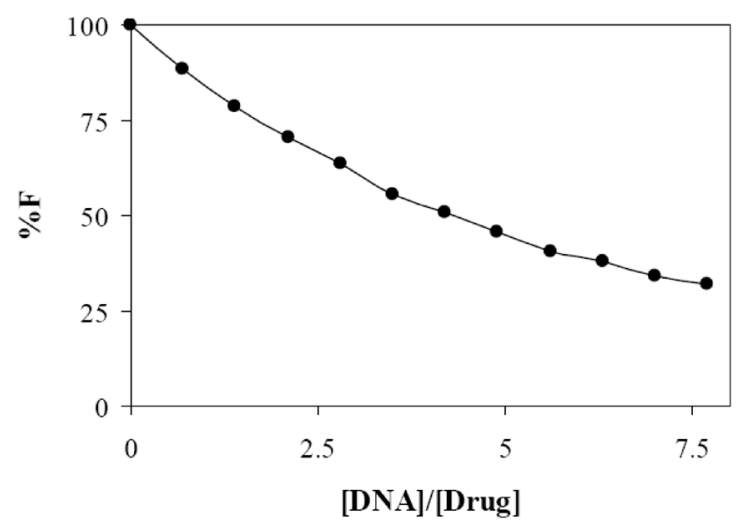

Figure 9. The plot of fluorescence intensity (F\%) versus $C_{\mathrm{DNA}} / C_{\text {doxorubicin }}$ at fluorescence wavelength of $590.0 \mathrm{~nm}$. Conditions: phosphate buffer $\left(0.01 \mathrm{~mol} \mathrm{~L}^{-1}, \mathrm{pH} 7.4\right)$ plus $\mathrm{NaCl}\left(0.05 \mathrm{~mol} \mathrm{~L}^{-1}\right), C_{\text {doxorubicin }}=1.0 \mu \mathrm{mol} \mathrm{L}{ }^{-1}$, excitation wavelength $480 \mathrm{~nm}^{40}$

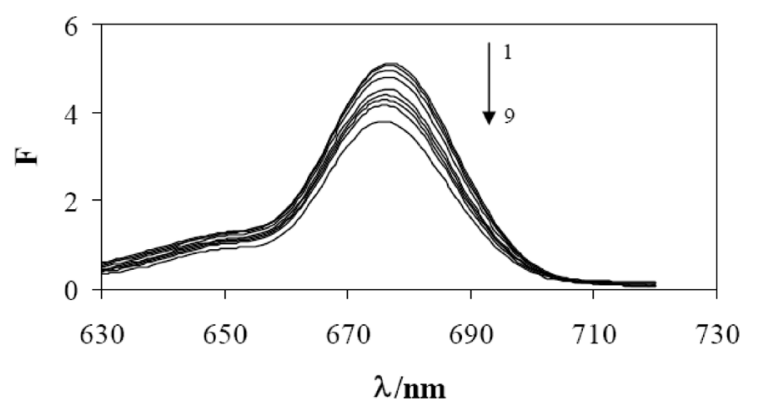

Figure 10. Synchronous fluorescence spectra of methylene blue in the presence of DNA. $C_{\mathrm{DNA}}=0.0,2.93,5.86,11.0,20.7,25.1,29.3,33.3$ and $46.5 \mu \mathrm{mol} \mathrm{L} \mathrm{L}^{-1}$ for curves $1-9$, and $C_{\mathrm{MB}}=10.0 \mu \mathrm{mol} \mathrm{L}^{-1}$ in phosphate buffer (0.01 mol L-1, pH 7.4) plus $\mathrm{NaCl}\left(0.05 \mathrm{~mol} \mathrm{~L}^{-1}\right), \Delta \lambda=15 \mathrm{~nm}$.

the absence and presence of ds-DNA respectively. It is clear that the fluorescence of MB was not completely quenched by ds-DNA, indicating that only a fraction of the binding sites quenches the fluorescence.

$\frac{\mathrm{F}_{0}}{\mathrm{~F}}=1+\mathrm{K}_{\mathrm{SV}}[\mathrm{DNA}]$ 


\section{Conclusions}

In this research, the interaction of anticancer drug (doxorubicin) with ds-DNA has been investigated by UVVis spectrophotometry, differential pulse voltammetry and spectrofluorometry. All the acquired spectral data showed that a new adduct between doxorubicin and DNA is formed. In solution, the drug can bind to ds-DNA with a binding constant of $\mathrm{K}=3.2( \pm 0.24) \times 10^{4} \mathrm{~L} \mathrm{~mol}^{-1}$. The quenching constant $\left(\mathrm{K}_{\mathrm{Sv}}\right)$ for methylene blue-DNA system was determined $7.60( \pm 0.71) \times 10^{3} \mathrm{~L} \mathrm{~mol}^{-1}(\mathrm{n}=4)$ by Stern-Volmer equation.

The UV-Vis spectrophotometry, electrochemistry and spectrofluorometry techniques show an intercalation mechanism between drug doxorubicin and ds-DNA.

To the best of our knowledge, it is the first method that allows investigation on the interaction between doxorubicin and DNA using spectrofluorometry and UV-Vis spectrophotometry methods. In conclusion, the above system offers a practical potential for study on the drug-DNA interactions with some advantages such as simplicity, good repeatability, suitable speed and low cost devices which have not been presented together in the previously reported articles.

\section{Acknowledgments}

The authors gratefully acknowledge the financial support of this work by Azad University branch of Gachsaran. The authors also thank Dr. Mahshad Yaran from Red cross drug store in Isfahan city for her cooperation.

\section{References}

1. Grguric-Sipka, S. R.; Vilaplana, R. A.; Perez, J. M.; Fuertes, M. A.; Alonso, C.; Alvarez, Y.; Sabo, T. J.; Gonzalez-Vilchez, F.; J. Inorg. Biochem. 2003, 97, 215.

2. Rauf, S.; Gooding, J. J.; Akhtar, K.; Ghauri, M. A.; Rahman, M.; Anwar, M. A.; Khalid, A. M.; J. Pharm. Biomed. Anal. 2005, $37,205$.

3. Goldberg, I. H.; Beerman, T. A.; Poon, R.; Cancer, Plenum Press: New York, 1997.

4. Neidle, S.; Progress in Medicinal Chemistry, Elsevier/NorthHoUand Biomedical Press: Amsterdam, 1979.

5. Blake, A.; Peacocke, A. R.; Biopolymers 1968, 6, 1225.

6. Waring, M. J.; The Molecular Basis of Antibiotic Action, John Wiley: London, 1972.

7. Miller, W.; Crothers, D. M.; J. Mol. Biol. 1968, 35, 251.

8. Wang, J. C.; J. Mol. Biol. 1974, 89, 783.

9. Angerer, L. M.; Gerghiou, S.; Moudrianakis, E. N.; Biochemistry 1974, 13, 1075.
10. Lurquin, P. F.; Chem. Biol. Interact. 1974, 8, 303.

11. Lawrence, J. J.; Daune, M.; Biochemistry 1976, 15, 3301.

12. Paoletti, J.; Magee, B. B.; Magee, P. T.; Biochemistry 1977, 16, 351.

13. Houssier, C.; Bontemps, J.; Edmonds-Aft, X.; Fredericq, E.; Ann, N. Y.; Acad. Sci. 1977, 303, 170.

14. Wartell, R. M.; Larson, J. E.; Wells, R. D.; J. Biol. Chem. 1975, 250, 2698.

15. Soben, H. M.; Reddy, B. S.; Bhandary, K. K.; Jain, S. C.; Sakore, T. D., Seshadri, T. P.; Symp. Quant. Biol. 1978, 42, 87.

16. Lown, J. W.; Anthracycline and Anthracenedione-Based Anticancer Agents, Elsevier: Amsterdam, 1988.

17. Priebe, W.; Anthracyclines Antibiotics. New Analogs, Methods of Delivery, and Mechanisms of Action, American Chemical Society: Washington, DC, 1995.

18. Raffaelli, A.; Pucci, S.; Desideri, I.; Bellina, C. R.; Bianchi, R.; Salvadori, P.; J. Chromatogr., A 1999, 854, 57.

19. Bale, M. J.; Yang, C.; Pfaller, M. A.; Diagn. Microbiol. Infect. Dis. 1997, 28, 65.

20. Usacheva, M. N.; Teichert, M. C.; Biel, M. A.; J. Photochem. Photobiol., B 2003, 71, 87.

21. Li, W. Y.; Xu, J. G.; Guo, X. Q.; Zhu, Q. Z.; Zhao, Y. B.; Anal. Lett. 1997, 30, 527.

22. Armstrong, R. W.; Kurucsv, T.; Strauss, V. P.; J. Am. Chem. Soc. 1970, 92, 3174.

23. Erdem, A.; Kerman, K.; Meric, B.; Ozsoz, M.; Electroanal. 2001, 13, 219.

24. Ohuigin, C.; McConnell, D. J.; Kelly, J. M.; Van der Putten, W. J. M.; Nucleic Acids Res. 1987, 15, 7411.

25. Fujimoto, B. S.; Clendenning, J. B.; Delrow, J. J.; Heath, P. J.; Schurr, M.; J. Phys. Chem. 1994, 98, 6633.

26. Kelly, S. O.; Barton, J. K.; Jackson, N. M.; Hill, M. G.; Bioconjugate Chem. 1997, 8, 31.

27. Norden, B.; Tjerneld, F.; Biopolymers 1982, 21, 1713.

28. Britos, L.; Goyenola, G.; Orono, S. U.; Biochem. Mol. Biol. Educ. 2004, 32, 341.

29. Di Marco, A.; Areamone, F.; Zunino, F.; Antibiotics, SpringerVerlag: Berlin, 1975.

30. Manfait, M. ; Alixl, A. J. P. ; Jeannesson, P.; Jardillier, J. C.; Theophanides, T.; Nucleic Acids Res. 1982, 10, 3803.

31. Manfait, M.; Theophanides, T.; Biochem. Biophys. Res. Commun. 1983, 116, 321.

32. Haj, H. T. B.; Salerno, M.; Priebe, W.; Kozlowski, H.; GarnierSuillerot, A.; Chem.-Biol. Interact. 2003, 145, 349.

33. Ibrahim, M. S.; Shehatta, I. S.; Al-Nayeli, A. A.; J. Pharm. Biomed. Anal. 2002, 28, 217.

34. Long, E. C.; Barton, J. K.; Acc. Chem. Res. 1990, 23, 271.

35. Huang, C. Z.; Li, Y. F.; Feng, P.; Talanta 2001, 55, 321.

36. Ensafi, A. A.; Hajian, R.; Ebrahimi, S.; J. Braz. Chem. Soc. 2009, 20, 266.

37. Ni, Y.; Du, S.; Kokot, S.; Anal. Chim. Acta 2007, 584, 19. 
38. Carter, M. T.; Rodoriguez, M.; Bard, A. J.; J. Am. Chem. Soc. 1989, 111, 8901.

39. Radi, A.; El Ries, M. A.; Kandil, S.; Anal. Bioanal. Chem. 2005, $381,451$.
40. Bagalkot, V.; Farokhzad, O. C.; Langer, R.; Jon, S.; Angew. Chem., Int. Ed. 2006, 45, 1. 